\title{
THE SEQUOIAS
}

By T. P. LUKENS

Pasadena, California

RIOR to the Glacial Period, the Sequoias were widely planted over
three continents, but now they are limited to small areas in Cali-
fornia alone.

The Sequoia sempervirens, commonly known as Redwood, grows only along the west coast of California, from near the Oregon line southerly for about two hundred and sixty miles, and nowhere does it grow further than twenty-five miles from the sea; perhaps ninety-five per cent are growing within ten miles of the coast. At no place is it found at a high elevation.

The uses to which the lumber of the Redwood is put are known to all. It is the only conifer indigenous to California that will sprout from the stump. This adds much to its value as a forest tree. With reasonable care after harvesting in keeping out fire, a new forest will soon take the place of the old.

Teachers visiting San Francisco who so desire can have an object lesson on the wonderful power of reproduction by this tree at Mill Valley in Marin County. Eere was the first lumbering in California; the first trees having been cut in 1835 and from that time on until 1860 . And here will be found, close to the station in Mill Valley, a circle of sprouts; each tree about two feet in diameter and from forty to eighty feet in height, the third generation of what may have been the largest redwood ever known. I ascertained that this tree was cut in 1835, the first set of sprouts was cut in 1875 , now there is twenty thousand feet of lumber in the third growth. There is no portion of the old tree left, it having decayed or been removed, but the circle is perfect and the diameter inside this circle is thirty-eight feet, so the tree was presumably thirty-eight feet in diameter at the ground. This and other wonderful trees can be seen about Mill Valley in an easy half day's trip from San Francisco, but make it a whole day and go on to Mt. Tamalpais and the Muir Woods. On this trip you will see several hundred giant trees not only Redwood but Douglas spruce and Chestnut oak, a sight well worth a trip across the continent. Muir Woods consists of two hundred and ninety-five acres of forest on the southerly slope of Mt. Tamalpais, and was the gift of William Kent to the United States as a Redwood preserve. It contains many grand specimens. Mr. Kent gave this valuable property to the United States Government with the understanding that it should be cared for as a park for the benefit of all and that it should be named for John Muir, our beloved mountain friend.

The State of California owns several thousand acres of redwood forest in the Santa Cruz mountains, which are easily reached in a day from 
San Francisco. The quickest way to reach the State Park or Big Basin is via Los Gatos to Boulder City. From this point there is a stage ride of fourteen miles to the Governor's Camp, which is located under the grand old trees. If one can spend two nights and a day he will be richly rewarded. Here are:-several thousand trees, many of which are from fifteen to twenty-five feet in diameter and reaching far up into the sky; the Douglas spruce, a close second to the redwood, also magnificent oaks, azaleas and a beautiful carpeting of ferns and flowers. This trip, if you are at all a lover of God's wild gardens, will repay you for a trip around the world.

To see the big brother of the redwood, the Sequoia washingtonia or gigantia, one must travel further, for this tree grows only in the Sierra Nevada mountains. The most northerly grove contains but six trees, and is located on the Middle Fork of the American river, at about five thousand feet elevation in Placer County. These trees appear also on the westerly slope of the Sierra Nevada at from five thousand to eight thousand five hundred feet above sea level, and extend for a distance north and south of about two hundred fifty miles. Tulare County is their southern limit. The Bigtree Grove most accessible from the Bay is the Calaveras, or "Mammouth," which includes the South Grove or the Stanislaus, the first grove found, and this was discovered by John Bidwell in 1841. There are more very large trees in this grove than in any other. For this trip take ticket by rail to Sonora, Tuolumne County; stage fifteen miles; there is a good hotel.

If you can spend four or more days, go to Yosemite by rail, stage from Yosemite to Wawona. This is an easy one-half day stage ride through grand forest and mountain scenery to the South Fork of the Merced river. Wawona is one of the best, if not the best mountain resort in California. From the hotel you can ride in a comfortable carriage, or stage, or go on horseback to the Mariposa Grove. Upon the ride of about seven miles from the hotel to the Bigtrees you will wonder what they (the Bigtrees) can be, if they are larger than the trees you are passing; on every side are Sugar pine, Douglas spruce, White and Red fir, and Libocedrus, larger than any trees you have ever seen outside California; many from eight to fourteen feet in diameter and three hundred feet high; so in the climb from Wawona to the Bigtrees you are in a measure prepared for the inspiration you experience when in the presence of these monarchs who were witnesses to our blessed Savior's stay on earth. Now that you are with God's grandest production in the vegetable kingdom, tarry, for it takes time to fully realize their grandeur, then you will feel repaid many times for the trip, and thank God anew for $\mathrm{His}$ goodness.

Take a ball of twine with you, run around a big tree with the cord, take it (the cord) home with you, and unwind it in a company of friends 
or in the presence of your pupils, and see their astonishment in learning that there is a tree growing that is so great in diameter.

If you visit Sequoia Groves further south, you will find natural reforestation at work, little hopefuls from one inch high to the monarchs, and you will find them growing over ridges and canons, never exclusively, but peacefully growing with other species of conifers and broadleaf trees, displaying no haughtiness because of their superiority over all the vegetable kingdom.

You can easily reach the more southerly groves from Fresno or Visalia, from the latter place, the General Grant Park.

If possible secure before you make the trip "Forest Trees of the Pacific Slope" by Geo. B. Sudworth, Dendrologist, issued October 1st, 1908 , by U. S. Forest Service. Then no tree will be a stranger to you. If not able to secure this, take Sargent's "Manual of the Trees of North America," or any other work that describes all the trees, or Bulletin No. 28, Division of Forestry, "The Big Trees of California," or John Muir's "Mountains of California."

Seeing and knowing what you see, you will be stronger and better. Remember that you leave all danger of accident or sickness in the cities so give no thought for your safety while in God's gardens and temples.

\section{THE CALIFORNIA OIL INDUSTRY}

By Ralph Arnold

Consulting Geologist and Engineer, Los Angeles, California

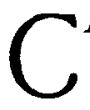
ALIFORNIA 'stands first among the states in the production and value of its petroleum. In 1909 it produced 56,910,449 barrels, valued at $\$ 34,856,126$. In 1910 the estimated production was 75 , 000,000 barrels. Furthermore, oil is the most important mineral product of the State, outranking gold, its nearest competitor, by $\$ 14,000,000$ in 1909 .

The great bulk of California oil is not like that from the eastern and midcontinent fields. It has what is termed an asphaltum base and is better suited for fuel purposes than is the lighter, paraffine-base oil from the east, which is largely of a refining grade; only about 20 per cent of the California product is suitable for refining.

Again, the petroleum in California occurs in rock formations much younger, geologically speaking, than those yielding the oil in Pennsylvania, Ohio, Illinois and Oklahoma. The oil here occurs in the Tertiary while in the east it occurs in the Paleozoic rocks. 